\title{
A Prospective Interventional Study on Prescription Auditing, Adverse Drug Reaction Monitoring and Health Related Quality of Life of Patients in a Tertiary Care Teaching Hospital in South Kerala
}

\author{
Bismi S', Chintha Chandran', Deepthi Mariya Davis ${ }^{1}$, Dhanya SS ${ }^{1,}$, , Dhanya Dharman ${ }^{2}$, Shaiju S Dharan ${ }^{1}$
}

\section{Bismi S1, \\ Chintha Chandran', Deepthi Mariya Davis', Dhanya SS ${ }^{1, *}$, Dhanya Dharman², Shaiju S Dharan ${ }^{1}$}

'Department of Pharmacy Practice, Ezhuthachan College of Pharmaceutical Sciences Marayamuttom, Neyyattinkara, Thiruvananthapuram, Kerala, INDIA. ${ }^{2}$ Department of Pharmacy Practice, Ezhuthachan College of Pharmaceutical Sciences Marayamuttom, Neyyattinkara, Thiruvananthapuram, Kerala, INDIA.

Correspondence

Ms. Bismi S

Pharm D Student, Ezhuthachan College of Pharmaceutical Sciences,

Marayamuttom, Neyyattinkara, Thiruvananthapuram-695124, Kerala, INDIA.

Phone no: +91-9447927238

Email: ssdhanya25@gmail.com

History

- Submission Date: 16-07-2021

- Revised Date: 31-08-2021

- Accepted Date: 11-09-2021

DOI : 10.5530/ijmedph.2021.4.39

Article Available online

http://www.ijmedph.org/v11/i4

\section{Copyright}

(C) 2021 Phcog.Net. This is an openaccess article distributed under the terms of the Creative Commons Attribution 4.0 International license.

\begin{abstract}
Background: Prescription auditing is one of the important tool to avoid misuse of drugs and improves rational use of drugs. The performance of the health care providers related to the appropriate use of drugs can be accessed by analyzing the different prescribing indicators. An Adverse Drug Reaction (ADR) can be defined as 'an appreciably harmful or unpleasant reaction resulting from an intervention related to the use of a medicinal product. This can be assessed by using probability scale, severity assessment scales, etc. Objectives: The main objective of the study was to audit the prescriptions, evaluate the incidence of ADR and assess health related quality of life. Methodology: A Prospective interventional study was conducted in a tertiary care teaching hospital in south Kerala during the study period of 6 months. A total no. of 235 inpatients in general medicine department were included during the study. Results: Out of 235 prescriptions, 1742 drugs were analyzed using prescription auditing checklist. The average no. of drugs were prescribed about 7.41. The incidence of ADRs is 0.025 and 6 were identified and analyzed using Naranjo scale and Hartwig severity assessment scale. In health related quality of life shows significance in age, BMI, gender, socioeconomic status and prescribing indicators in different aspects. Conclusion: There is a need for improvement in the standards of prescription patterns in all aspects. The health related quality of life will helps to assess physical and mental attitudes of patients which may affect their drug therapy.

Key words: Prescription Auditing, Adverse Drug Monitoring, Health Related Quality of Life (HRQOL).
\end{abstract}

\section{INTRODUCTION}

Prescription auditing is one of the important tool to avoid misuse of drugs and improves rational use of drugs. The performance of the health care providers related to the appropriate use of drugs can be accessed by analyzing the different prescribing indicators. The quality of a prescription reflects the competence of a physician and his attitude towards rational prescribing. However, systematic reviews suggest that prescribing errors are common and can affect from 4.2 to $8.2 \%$ of prescriptions. ${ }^{1}$

These prescribing errors can also cause adverse effects. Almost four in 1000 prescriptions have errors that have the potential for causing adverse effects. ${ }^{2}$ Error can arise from any step of prescribing such as the choice of drug, dose, route of administration and wrong frequency or duration of treatment. Inaccuracy in writing and poor legibility of handwriting or incomplete writing of a prescription can lead to misinterpretation, thus leading to errors in dispensing and administration. Prescription Indicators -Medicines play crucial role in the delivery of healthcare service across the globe. Appropriate use of medicines can contribute immensely to reducing morbidity and mortality.

Inappropriate use of medicines is deemed to be more of a problem in the global South. This is seen to have potential implications on healthcare budgets as almost $25-70 \%$ of worldwide healthcare expenditure is spent on medicines..$^{10}$ In this sense, improvement in medicine use behaviors is seen as a step towards optimizing the use of limited health resources and also improving the quality of healthcare delivery. To highlight the need for attention into medicines usage, the WHO has been compiling medicines use from different parts of the world and publishing in its World Medicines Situation Reports since 1988. ${ }^{3}$ The WHO has also championed efforts towards streamlining how information on medicine use are collated. In the early nineties, the WHO collaborated with the International Network for Rational Use of Drugs (INRUD) to develop a set of "core drug use indicators." The indicators measure 
performance in three related areas of "prescribing practices, patient care, and facility-specific factors." The core drug use indicators have come to be recognized as "objective measures that can describe the drug use situation in a country, region or individual health facility." 4,5 Adverse drug reactions (adverse effects) are any unwanted effects of a drug. ${ }^{6}$

\section{There are several different types}

Dose-Related Adverse Drug Reactions -It represent an exaggeration of the drug's therapeutic effects. For example, a person taking a drug to reduce high blood pressure may feel dizzy or light-headed if the drug reduces blood pressure too much. A person with diabetes may develop weakness, sweating, nausea, and palpitations if insulin or an oral antidiabetic drug reduces the blood sugar level too much. This type of adverse drug reaction is usually predictable but sometimes unavoidable. It may occur if a drug dose is too high (overdose reaction), if the person is unusually sensitive to the drug, or if another drug slows the metabolism of the first drug and thus increases its level in the blood. Dose-related reactions are usually not serious but are relatively common. Allergic Drug Reactions. These are not dose-related but require prior exposure to a drug. Allergic reactions develop when the body's immune system develops an inappropriate reaction to a drug (sometimes referred to as sensitization). After a person is sensitized, later exposures to the drug produce one of several different types of allergic reaction. Sometimes doctors do skin tests to help predict allergic drug reactions.

Health-related quality of life (HRQoL) is a concept encompassing subjective and objective benchmarks that allude to physical and psychosocial well-being. ${ }^{20}$ Assessment of HRQoL among the general population has become an international concern due to aging populations, the growing prevalence of chronic conditions and the increasing cost of healthcare. ${ }^{9}$ HRQoL is often used to monitor the health status of populations and to inform public health and healthcare policy, therefore it has great benefits for economic evaluation..$^{10}$ Due to the importance of HRQOL, the Institute of Medicine incorporated it as one of 20 benchmarks to identify healthy people in 2020. ${ }^{11}$ (HRQoL) is a multi-dimensional concept that includes domains related to physical, mental, emotional, and social functioning. It goes beyond direct measures of population health, life expectancy, and causes of death, and focuses on the impact health status has on quality of life. A related concept of HRQoL is well-being, which assesses the positive aspects of a person's life, such as positive emotions and life satisfaction.

\section{AIM}

To audit prescriptions, evaluate the incidence of ADR and assess health related quality of life of patients.

\section{OBJECTIVES}

1. To assess the prescription pattern of drugs using prescription indicators in general medicine department.

2. To evaluate the incidence of ADR in general medicine department.

3. To find out and categorize ADRs.

4. To assess the health related quality of life of patients.

\section{Methodology}

\section{Study area or settings}

The study was carried out under general medicine department of NIMS Medicity, Neyyattinkara, a tertiary care hospital in Trivandrum.

\section{Study Population}

The inpatients from General Medicine Department of NIMS Medicity.

\section{Sample Size}

According to OpenEpi, version 3, open source calculator, the sample size at $95 \%$ confidence interval is 235 .

\section{Study Design}

A Prospective Interventional study.

\section{Criteria for patient selection}

\section{Inclusion Criteria}

- Patients who attained the inpatient in general medicine department.

- Male \& female patients.

- $\quad$ Patients aged greater than 15 years

\section{Exclusion Criteria}

- Patients who were not willing to participate in the study.

- Pediatric, psychiatric patients, pregnancy and lactating women.

\section{Sampling Technique}

Consecutive Sampling technique- It is a sampling technique in which every subject meeting the criteria of inclusion is selected until the required sample size is achieved.

\section{Study Duration}

The prospective interventional study was carried out for over a period of 6 months commencing from October 2019 to March 2020 among inpatients of General medicine departments.

\section{Study Variables}

- Socioeconomic factors

- WHO prescribing indicators

- Drug prescribing pattern

- Health related quality of life by using sf 36 questionnaire

- Naranjo scale

- Hartwig's severity assessment scale

\section{Data Collection and Analysis}

- Prescriptions was randomly selected from general medicine department and check all the parameters of prescription audit as per the checklist. The validity of these data was confirmed against the databases like Micromedex, Medscape and Medline.

- Casualty assessment of the Adverse Drug Reactions (ADRs) was done by using Naranjo scale. Subsequently, the severity will be assessed using the Hartwig's severity assessment scale. Each ADR was documented in suspected adverse drug reaction reporting form issued by the Central Drug Standard Control Organization (CDSCO) and reported to the Clinical Pharmacy Department of NIMS Medicity, Neyyattinkara, Thiruvananthapuram. After data transcription and data cleaning, various prescribing indicators were calculated using the following formula adopted from manual of prescribing indicators by WHO.

- The collected data was filled in prescription audit checklist and assessed the retrieved data.

- A questionnaire (SF-36 questionnaire) form was prepared for assessing the health related quality of life in patients comparing with prescription auditing. The collected data was recorded and analyzed using MS Excel spreadsheet and SPSS version 17.0. 


\section{Description of tool used}

- Data collection form- is a way of recording approach to obtaining the data that are need to perform the analysis.

- Kuppasamy socioeconomic scale -used to measure socioeconomic status in urban and rural areas.

- Central Drug Standard Control Organization (CDSCO) Form- It is used to record ADRs by patient.

- Naranjo scale- It is a questionnaire for determining the likelihood of whether an ADR is actually due to drug rather than the result of other factors.

- Hartwig's severity scale- It is used for assessing severity of identified ADRs.

- WHO Prescribing Indicators-It is used for assessing the performance of the health care providers related to the appropriate use of drugs.

- Prescription audit checklist- It is a checklist used to check out the relevant details are in a prescription.

- Health related quality of life questionnaire-SF-36

\section{RESULTS AND DISCUSSION}

\section{Distribution of Gender}

Out of 235 patients studied, $50.2 \%(n=118)$ were females and $49.8 \%$ $(n=117)$ were males. The result shows that majority of patients were female. But in the study of Balbir et al., 54\% of males and $45.83 \%$ females were included, males were dominant than females. ${ }^{13}$

\section{Distribution of Age}

Out of 235 patients studied, the most prominent age group found in between 41-60 years of age 33.6\% ( $n=79)$. In the study of Balbir et al., $44.09 \%$ were in the age group of $41-60$ years, which is higher than our study. ${ }^{15}$

\section{Distribution of Body Mass Index}

Among 235 patients $3.0 \%(n=7)$ were below normal, $39.6 \%(n=93)$ were normal, $51.9 \%(n=122)$ were overweight, $4.7 \%(n=11)$ were class 1 obesity and $0.9 \%(n=2)$ were class 2 and class 3 obesity. There is no any relevant studies were available for BMI analysis.

\section{Distribution of Disease}

The most common disease pattern seen in patients attended in general medicine IPD of our hospital was diseases of respiratory system accounting

$\begin{aligned} & \text { Table 1: Frequency and percentage distribution of samples according } \\
& \text { to sex }(\boldsymbol{n}=\mathbf{2 3 5}) .\end{aligned}$
\begin{tabular}{ccc} 
Sex & Frequency & Percentage \\
\hline Female & 118 & 50.2 \\
Male & 117 & 49.8 \\
\hline
\end{tabular}

\begin{tabular}{|c|c|c|c|c|}
\hline $\begin{array}{c}\text { Age in } \\
\text { years }\end{array}$ & Frequency & Percentage & Range & Mean \pm SD \\
\hline$\leq 20$ & 11 & 4.7 & \multirow{5}{*}{ 19- 95} & \multirow{5}{*}{$51.46 \pm 18.55$} \\
\hline $21-40$ & 61 & 26.0 & & \\
\hline $41-60$ & 79 & 33.6 & & \\
\hline $61-80$ & 72 & 30.6 & & \\
\hline$>80$ & 12 & 5.1 & & \\
\hline
\end{tabular}

\begin{tabular}{|c|c|c|c|c|}
\hline $\begin{array}{l}\text { Body Mass } \\
\text { Index }\end{array}$ & Frequency & Percentage & Range & Mean \pm SD \\
\hline$\leq 18$ & 7 & 3.0 & & \\
\hline $18.01-23.99$ & 93 & 39.6 & & \\
\hline 24- 29.99 & 122 & 51.9 & $15.60-40.00$ & $24.70 \pm 3.42$ \\
\hline $30-34.99$ & 11 & 4.7 & & \\
\hline$\geq 35$ & 2 & 0.9 & & \\
\hline
\end{tabular}

for $27.6 \%$, followed by endocrine system (18.29\%), infectious and parasitic diseases (11.06\%), diseases of digestive system and cardiovascular system. In the study of Abidi et al., disease of respiratory system were about $44.72 \%(n=237)^{18}$ which is in higher rate shows the intensity of same disease condition in different geographical areas due to climate conditions, pollution by industrialization, deforestation, etc.

\section{Distribution of Prescribed Drugs of Antibiotics}

The most common antibiotics prescribed are cephalosporin's $(59.66 \%)$ which include second and third generation cephalosporin's followed by beta lactams (15.43\%), tetracycline (7.63\%), macrolides (5.62\%), Fluoroquinolones $(4.41 \%)$ and metronidazole (3.61\%). The related relevant articles were not specified about the prescribed drugs of antibiotics.

\section{Distribution of Prescription Auditing Checklist}

Basic information of patients like name, age, sex and complete address were written in $100 \%$ of prescription. Completeness in terms of dose (79.14\%), route $(88.51 \%)$, frequency and time $(94.04 \%)$, legible $(72.76 \%)$ were recorded. Only $79.57 \%$ of prescription were legible. Therefore proper training and education of physician is necessary regarding legibility and completeness of prescription in all aspects. In Solanki ND et al., dose (96\%), route (96\%), frequency (92.6\%) and legible (96\%) shows that lower rates in our prescription. ${ }^{16}$ This implicates more chances of cause medication errors, drug interactions, polypharmacy, and other drug related problems.

\section{Drug Interactions}

The total no. of drug interactions in our study was identified as 51 . Out of that 3 were major, 20 were moderate and 28 were minor interactions. In other related studies shows that drug interactions were not applicable in their auditing. ${ }^{16}$

\section{Identification of Drug Interactions}

In our study, minor interactions (54.90\%) higher than moderate (39.21\%) and major interactions (5.88\%) out of 51 identified interactions. Whenever the discontinuation of interacted drug to cause ADR were not possible, essential monitoring parameters based on expected effect were suggested. ${ }^{17}$

\section{Medication Errors}

Medication errors are one of the major causes of drug related problem which may leads to serious health issues if unprevented. In our study, most medication error related issues were about omission or mistaken of dosage form, dose, route of administration, frequency and timing, illegible handwriting, decimal point errors, use of non-standard abbreviations in which almost were corrected. But in the study of Sah et al., analyzed medication errors including skill based technical error, administration error, knowledge based error and rule based error, ${ }^{17}$ which were somewhat different types of medication errors than this study. 


\begin{tabular}{|c|c|c|c|c|}
\hline S.no & Interacted drugs & Severity & Effect & Management \\
\hline 1 & $\begin{array}{l}\text { Tramadol/Acetaminophen } \\
+ \text { Gabapentin }\end{array}$ & Major & $\begin{array}{l}\text { CNS depressants may enhance the } \\
\text { CNS depressant effect of opioid agonist }\end{array}$ & $\begin{array}{l}\text { Avoid concomitant use. } \\
\text { If it is used together, monitor the risk of slowed or difficult breathing } \\
\text { and/ or sedation }\end{array}$ \\
\hline 2 & $\begin{array}{l}\text { Tramadol/Acetaminophen } \\
+ \text { Levocetirizine }\end{array}$ & Major & $\begin{array}{l}\text { CNS depressants may enhance the } \\
\text { CNS depressant effect of opioid agonist }\end{array}$ & $\begin{array}{l}\text { Avoid concomitant use. } \\
\text { If it is used together, monitor the risk of slowed or difficult breathing } \\
\text { and/ or sedation }\end{array}$ \\
\hline 3 & $\begin{array}{l}\text { Domperidone }+ \\
\text { Escitalopram }\end{array}$ & Moderate & $\begin{array}{l}\text { QT prolonging agents may enhance the } \\
\text { QT prolonging effect of domperidone }\end{array}$ & $\begin{array}{c}\text { Consider alternatives therapy. If it is used, monitor for QT interval } \\
\text { prolongation and arrhythmias and also other cardiovascular risk } \\
\text { factors are likely at greater risk for these potentially life threatening } \\
\text { toxicities }\end{array}$ \\
\hline 4 & Deflazacort + Diltiazem & Major & $\begin{array}{l}\text { Diltiazem may increase serum } \\
\text { concentration of the active metabolites } \\
\text { of Deflazacort }\end{array}$ & $\begin{array}{l}\text { Administer one third of the recommended deflazacort dose when } \\
\text { used together with a strong or moderate CYP3A4 inhibitor }\end{array}$ \\
\hline 5 & $\begin{array}{l}\text { Furosemide }+ \text { Methyl } \\
\quad \text { Prednisolon }\end{array}$ & Moderate & $\begin{array}{l}\text { Corticosteroids may enhance the } \\
\text { hypokalemic effect of loop diuretics }\end{array}$ & $\begin{array}{l}\text { Monitor serum potassium. Addition of potassium sparing diuretic } \\
\text { and/or potassium supplementation may be necessary with } \\
\text { concomitant treatment }\end{array}$ \\
\hline
\end{tabular}

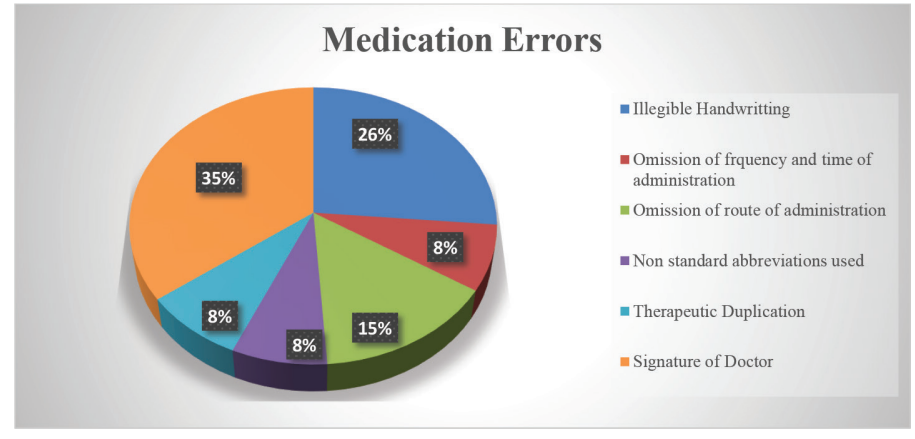

Figure 1: Pie chart shows percentage of most commonly occurred medication errors.

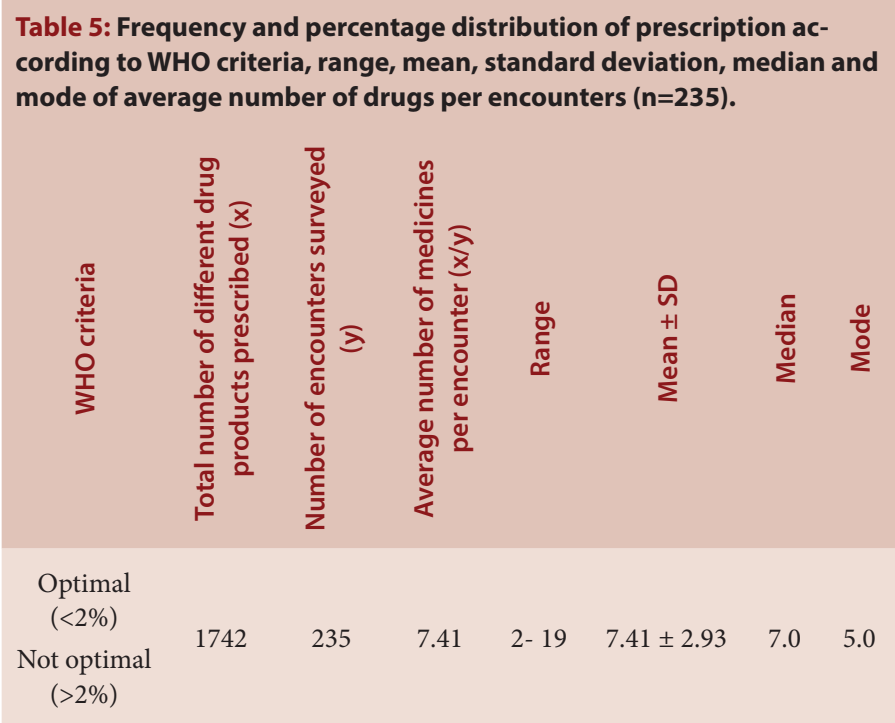

\section{Identification of Most Commonly occurred Medication Errors}

Total no. of Medication Errors: 182
Table 6: Frequency and percentage distribution of prescription according to WHO criteria, range, mean, standard deviation, median and mode of percentage of drug from generic name $(n=235)$.
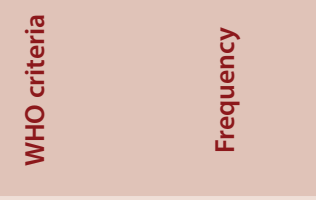

$\begin{array}{ccccccc}\text { Optimal }(100 \%) & 40 & 2.29 & 0-40 & 2.039 \pm 5.71 & 0 & 0\end{array}$

\section{Prescribing Indicators \\ Indicator 1: Average number of medicines per encounters}

The average no. of drugs per prescription was 7.41 , which is very much higher than WHO recommended limit of about 2.0. Increase in the number of average drugs per prescription may leads to polypharmacy which causes increase the risk of drug interaction and medication error. As four or more medications per day leads to polypharmacy, this result surely indicates polypharmacy. The polypharmacy level are higher in the studies of Balbir et al. (8.88), but lower in Abibi A et al. (4.22). ${ }^{18}$

\section{Indicator 2: Percentage of medicines prescribed by generic name}

Drugs were prescribed by generic name in only about a mean value of 2.039 and $2.29 \%$ of cases which is very low as compared to WHO recommended limit of $100 \%$ and in study of Balbir et al. (4.16\%). ${ }^{17}$ Prescribing pattern are being directly influenced by the Pharmaceutical companies. Generic prescribing reduces the chances of dispensing error which may be due to misinterpretation of LASA drugs and also decreases the economic burden on the patient. Hence, this shows the importance of generic drug prescribing and complies with WHO drug policies.

\section{Indicator 3: Percentage of encounters with an antibiotic prescribed}

The antibiotics prescribed were $91.06 \%$ of the patients and $14.29 \%$ of drugs which is more than the limits of WHO recommended level of 
Table 7: Frequency and percentage distribution of prescription according to WHO criteria, range, mean, standard deviation, median and mode of percentage of antibiotics prescribed $(n=235)$.

\begin{tabular}{|c|c|c|c|c|c|c|}
\hline 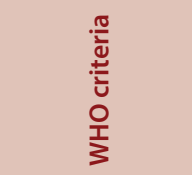 & 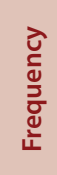 & 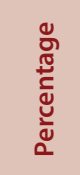 & 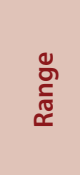 & 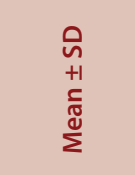 & $\frac{\sqrt{\pi}}{\frac{\pi}{\overline{0}}}$ & $\frac{0}{\circ}$ \\
\hline Optimal $(<30 \%)$ & 214 & 91.06 & \multirow{2}{*}{$\begin{array}{c}0- \\
66.67\end{array}$} & \multirow[t]{2}{*}{$1.17 \pm 0.61$} & \multirow[t]{2}{*}{1.0} & 1.0 \\
\hline $\begin{array}{l}\text { Not optimal } \\
\quad(>30 \%)\end{array}$ & 21 & 8.93 & & & & \\
\hline
\end{tabular}

Table 8: Frequency and percentage distribution of prescription according to WHO criteria, range, mean, standard deviation, median and mode of percentage of injections prescribed $(n=235)$.

\begin{tabular}{|c|c|c|c|c|c|c|}
\hline 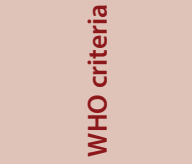 & 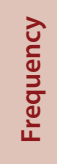 & 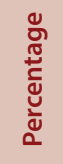 & 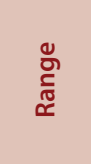 & 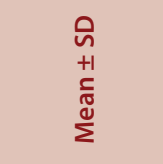 & 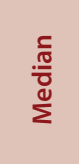 & $\begin{array}{l}\frac{\pi}{0} \\
\sum\end{array}$ \\
\hline Optimal $(<20 \%)$ & 45 & 19.1 & & & & \\
\hline $\begin{array}{l}\text { Not optimal } \\
\quad(>20 \%)\end{array}$ & 190 & 80.9 & $0-100$ & $35.90 \pm 16.61$ & 33.33 & 33.33 \\
\hline
\end{tabular}

$<30 \%$. But in the study of Balbir et al. where $11.84 \%$ of drugs were prescribed which is lower than that of our study. ${ }^{17}$ From the patients taking antibiotics, $26.63 \%$ of cases were prescribed more than one antibiotic which is much higher than that of Balbir et al. (8.33\%) but it is acceptable as compared to a study by Gupta et al. in which half of the patients i.e. $50 \%$ received more than one antibiotic this Figure is much lower. ${ }^{17}$ Appropriate use of antibiotics is absolutely necessary to prevent emergence of drug resistance and should be mostly used after culture sensitivity testing. Most of the acute respiratory and acute gastroenteritis cases are viral in nature and may not need antibiotics. An antibiotic policy should be formulated so that the clinicians can use them judiciously according to patients' need. ${ }^{19}$

\section{Indicator 4: Percentage of encounters with an injection prescribed}

The injection prescribed were about $19.1 \%$ of patients which are higher from WHO recommended $<30 \%$. But in the study of Balbir et al., injections were prescribed about $12.09 \%{ }^{17}$ which is higher in our study. We need to reduce the unnecessary use of injectable to prevent HIV and other blood borne injections.

\section{Indicator 5: Percentage of medicines prescribed from the essential medicines list}

Drugs from EDL were only about $11.9 \%$ as lower than WHO recommended limits of $100 \%$ which is decreased to about 20.63. In Balbir et al., this was found to be about $53.25 \%$ which is very lower than our value. But was still on the lower side. ${ }^{17}$

\section{Therapeutic Audit}

\section{Identification of Major Therapeutic Interventions}

The 65 interventional findings noted in our study which includes drugdrug interactions (DDIs), therapeutic duplications, medication errors,
Table 9: Frequency and percentage distribution of prescription according to WHO criteria, range, mean, standard deviation, median and mode of percentage of drug from essential medicine list $(n=235)$.

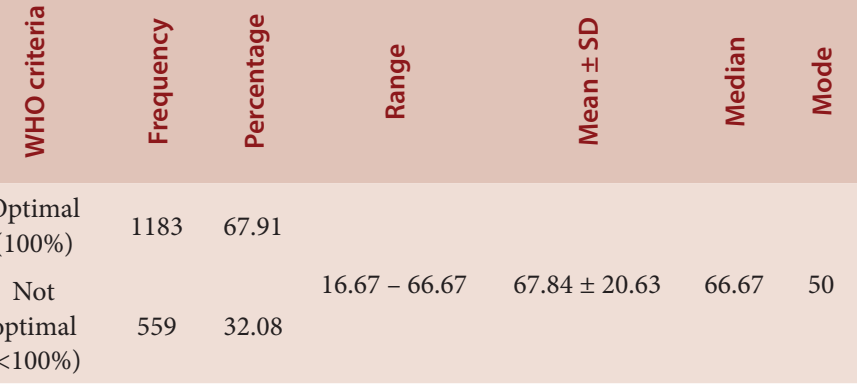

\section{Therapeutic Interventions}

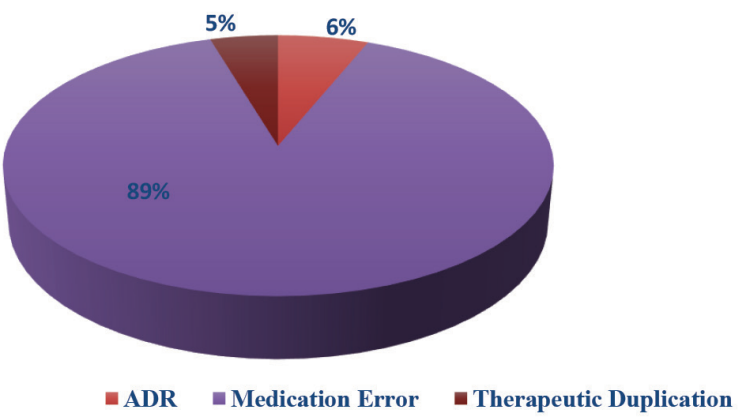

Figure 2: Pie chart shows percentage of major therapeutic interventions.

Table 10: Classification of suspected ADRs according to Naranjo scale and Hartwig severity scale.

\begin{tabular}{|c|c|c|c|c|}
\hline S.No & $\begin{array}{l}\text { Suspected } \\
\text { Drug }\end{array}$ & Reaction & $\begin{array}{l}\text { Naranjo } \\
\text { scale } \\
\text { score }\end{array}$ & $\begin{array}{c}\text { Hartwig } \\
\text { severity scale } \\
\text { score }\end{array}$ \\
\hline 1 & Methotrexate & $\begin{array}{l}\text { Bluish discoloration } \\
\text { over skin }\end{array}$ & $\begin{array}{c}\text { 8- } \\
\text { Probable }\end{array}$ & Mild- level 1 \\
\hline 2 & Hydrocortisone & Hyperglycemia & $\begin{array}{c}\text { 7- } \\
\text { Probable }\end{array}$ & Mild - level 1 \\
\hline 3 & Amlodipine & Pedal edema & $\begin{array}{c}3- \\
\text { Possible }\end{array}$ & Mild- level 2 \\
\hline 4 & $\begin{array}{c}\text { Cefaperazone + } \\
\text { sulbactam }\end{array}$ & $\begin{array}{c}\text { Redness over both } \\
\text { elbow }\end{array}$ & $\begin{array}{c}\text { 6- } \\
\text { Probable }\end{array}$ & $\begin{array}{l}\text { Moderate- } \\
\text { level } 3\end{array}$ \\
\hline 5 & $\begin{array}{c}\text { Thrombophobe } \\
\text { gel }\end{array}$ & Itching & $\begin{array}{c}\text { 6- } \\
\text { Probable }\end{array}$ & Mild- level 2 \\
\hline 6 & $\begin{array}{c}\text { Piperacillin+ } \\
\text { Tazobactam }\end{array}$ & Allergic reaction & $\begin{array}{c}\text { 6- } \\
\text { Probable }\end{array}$ & $\begin{array}{l}\text { Moderate- } \\
\text { level } 3\end{array}$ \\
\hline
\end{tabular}

pharmacovigilance survey, recommendation to select alternative drug and monitoring parameters. But in the study of Sah et al., about 40 therapeutic interventions were done which includes antibiotic stewardship, drug-drug interaction, therapeutic duplication, pharmacovigilance survey, the recommendation to select alternate drugs, monitoring parameters, dosage adjustment, medication errors and contraindication. ${ }^{18}$ 


\section{Adverse Drug Reactions Monitoring} Incidence of ADR

Incidence of the ADRs = total no. of suspected ADRs/ total no. of samples

$$
\begin{aligned}
& =6 / 235 \\
& =0.025
\end{aligned}
$$

In this study, from 235 prescriptions, only six ADRs were only suspected from General Medicine Department which having incidence rate of 0.025 in six month study duration that is comparatively higher than that of a study in Shrivastava M et al. $(3 / 219=0.013) .{ }^{20}$

\section{Health Related Quality of Life}

This study assesses the HRQoL among IPD of General Medicine Department during our study period. The mean age of the patient was 51.46 (SD \pm 18.55$)$ with highest age group of 41-60 years (33.6\%). More of the patients were female $(50.2 \%)$ and more of the patients were married $(88.9 \%)$. About $45.9 \%$ of patients were from lower middle socioeconomic level, followed by upper middle (23.4\%), upper lower (22.9\%), upper class and lower were of $3.8 \%$.

The mean total SF-36 score for the whole patients was about 57.42 which is comparatively lower than in the study of Laila M Matalqah et al. of mean 71.2, with the highest score reported for the Role limitation due

Table 11: Range, mean, standard deviation, median of health related quality of life in different domains $(n=235)$.

$\begin{array}{cccccc}\begin{array}{c}\text { Sl. } \\ \text { No }\end{array} & \text { Domains } & \text { Range } & \text { Mean } & \begin{array}{c}\text { Standard } \\ \text { deviation }\end{array} & \text { Median } \\ \text { 1. } & \text { Physical functioning } & 0-100 & 61.07 & 31.01 & 65.00 \\ \text { 2. } & \begin{array}{c}\text { Role limitations due to } \\ \text { physical health }\end{array} & 0-100 & 55.57 & 39.99 & 50.00 \\ & \begin{array}{c}\text { Role limitations due to } \\ \text { emotional problems }\end{array} & 0-100 & 63.63 & 39.36 & 66.60 \\ \text { 4. } & \text { Energy/fatigue } & 15-90 & 50.37 & 13.19 & 50.00 \\ \text { 5. } & \text { Emotional well-being } & 20-88 & 54.63 & 13.26 & 54.00 \\ \text { 6. } & \text { Social functioning } & 0-100 & 61.70 & 21.47 & 62.50 \\ \text { 7. } & \text { Pain } & 10-100 & 60.59 & 19.45 & 55.00 \\ \text { 8. } & \text { General health } & 0-100 & 51.80 & 14.86 & 50.00\end{array}$

Table 12: Correlation between quality of life score under

"physical functioning" with age and Body Mass Index ( $n=235)$.

$\begin{array}{ccccc} & r \text { value } & \begin{array}{c}\text { Type of } \\ \text { correlation }\end{array} & p \text { value } & \text { Inference } \\ \text { Age } & -0.678 & \text { Moderate negative } & <0.001 & \text { Significant } \\ \begin{array}{c}\text { Body Mass } \\ \text { Index }\end{array} & 0.083 & \text { Low positive } & 0.654 & \text { Not significant } \\ & & & & \\ \end{array}$

Table 13: Correlation between quality of life score under "Role limitations due to physical health"with age and Body Mass Index $(n=235)$.

$\begin{array}{ccccc} & \begin{array}{c}r \\ \text { value }\end{array} & \text { Type of correlation } & p \text { value } & \text { Inference } \\ \text { Age } & -0.576 & \text { Moderate negative } & <0.001 & \text { Significant } \\ \begin{array}{c}\text { Body Mass } \\ \text { Index }\end{array} & -0.003 & \text { Low negative } & 0.959 & \text { Not significant } \\ & & & & \end{array}$

Table 14: Correlation between quality of life score under "Role limitations due to emotional problems" with age and Body Mass Index ( $n=235)$.

\begin{tabular}{|c|c|c|c|c|}
\hline & $r$ value & Type of correlation & $p$ value & Inference \\
\hline Age & -0.487 & Moderate negative & $<0.001$ & Significant \\
\hline Body Mass Index & -0.032 & Low negative & 0.623 & $\begin{array}{c}\text { Not } \\
\text { significant }\end{array}$ \\
\hline
\end{tabular}

\begin{tabular}{ccccc} 
& $\boldsymbol{r}$ value & $\begin{array}{c}\text { Type of } \\
\text { correlation }\end{array}$ & $\boldsymbol{p}$ value & Inference \\
\hline Age & -0.490 & Moderate negative & $<0.001$ & Significant \\
$\begin{array}{c}\text { Body Mass } \\
\text { Index }\end{array}$ & 0.044 & Low positive & 0.498 & Not significant \\
\hline
\end{tabular}

\begin{tabular}{|c|c|c|c|c|}
\hline & $r$ value & $\begin{array}{c}\text { Type of } \\
\text { correlation }\end{array}$ & $p$ value & Inference \\
\hline Age & -0.559 & Moderate negative & $<0.001$ & Significan \\
\hline $\begin{array}{l}\text { Body Mass } \\
\text { Index }\end{array}$ & -0.001 & Low negative & 0.983 & $\begin{array}{c}\text { Not } \\
\text { significant }\end{array}$ \\
\hline
\end{tabular}

to emotional problem (63.63) and the lowest score for energy/fatigue (50.37). ${ }^{14}$

Correlation between in all eight domains with age is more significant $(p<0.001)$ as compared to BMI which shows age is one of the major factor in HRQoL was analyzed using Karl Pearson's coefficient of correlation. In our study, association between gender in case of some of the domains such as physical functioning, emotional well-being and general health are more significant than other domains $(p<0.01)$ was analyzed using Chi Square test.

The correlation between quality of life score under physical functioning with age shows more significant $(p<0.001)$ and had moderate negative relationship $(r$ value $=-0.678)$ than with body mass index with low positive relationship.

The correlation between quality of life score under role limitation due to physical health with age shows significant $(p<0.001)$ with moderate negative relationship ( $r$ value $=-0.576$ ) than body mass index with low negative relationship.

The correlation between quality of life score under role limitations due to emotional problems with age shows significant $(p<0.001)$ with moderate negative relationship ( $r$ value $=-0.490$ ) than body mass index with low positive relationship.

The correlation between quality of life score under energy/fatigue with age shows significant $(p<0.001)$ with moderate negative relationship $(r$ value $=-0.487)$ than body mass index with low negative relationship.

The correlation between quality of life score under emotional well-being with age shows significant $(p<0.001)$ with moderate negative relationship $(r$ value $=-0.559)$ than body mass index with low negative relationship.

The correlation between quality of life score under social functioning with age shows significant $(p<0.001)$ with moderate negative relationship $(r$ value $=-0.446)$ than body mass index with low positive relationship. 


\begin{tabular}{|c|c|c|c|c|}
\hline & $r$ value & Type of correlation & $p$ value & Inference \\
\hline Age & -0.446 & Moderate negative & $<0.001$ & Significant \\
\hline Body Mass Index & 0.027 & Low positive & 0.675 & $\begin{array}{c}\text { Not } \\
\text { significant }\end{array}$ \\
\hline
\end{tabular}

\begin{tabular}{|c|c|c|c|c|}
\hline & $r$ value & $\begin{array}{l}\text { Type of } \\
\text { correlation }\end{array}$ & $p$ value & Inference \\
\hline Age & -0.464 & $\begin{array}{c}\text { Moderate } \\
\text { negative }\end{array}$ & $<0.001$ & Significant \\
\hline Body Mass Index & 0.101 & Low positive & 0.124 & Not significant \\
\hline
\end{tabular}

\begin{tabular}{|c|c|c|c|c|}
\hline & $r$ value & $\begin{array}{l}\text { Type of } \\
\text { correlation }\end{array}$ & $p$ value & Inference \\
\hline Age & -0.538 & Moderate negative & $<0.001$ & Significant \\
\hline $\begin{array}{l}\text { Body Mass } \\
\text { Index }\end{array}$ & 0.025 & Low positive & 0.699 & Not significant \\
\hline
\end{tabular}

\begin{tabular}{|c|c|c|c|c|c|}
\hline \multirow[t]{2}{*}{ Gender } & \multicolumn{2}{|c|}{ Physical functioning } & \multirow[b]{2}{*}{$X^{2}$ value } & \multirow[b]{2}{*}{$\begin{array}{c}p \\
\text { value }\end{array}$} & \multirow[b]{2}{*}{ Inference } \\
\hline & $\begin{array}{c}\leq \text { median } \\
(\leq 65)\end{array}$ & $\begin{array}{c}>\text { median } \\
(>65)\end{array}$ & & & \\
\hline Male & 52 & 65 & \multirow{2}{*}{4.630} & \multirow{2}{*}{0.031} & \multirow{2}{*}{ Significant } \\
\hline Female & 69 & 49 & & & \\
\hline
\end{tabular}

$\chi^{2}$ at 0.05 level of significance

The correlation between quality of life score under pain with age shows significant $(p<0.001)$ with moderate negative relationship $(r$ value $=$ -0.464) than body mass index with low positive relationship.

The correlation between quality of life score under general health with age shows significant $(p<0.001)$ with moderate negative relationship $(r$ value $=-0.538)$ than body mass index with low positive relationship. But in the study of Laila M Matalqah et al. explains about ageing and obesity having relationship with quality of life in different aspects. ${ }^{15}$

The association between quality of life under physical functioning with gender shows significant $(p$ value $=0.031)$.

The association between quality of life under role limitations due to physical health and gender shows not significant ( $p$ value $=0.328$ ).

The association between quality of life under role limitations due to emotional problems in gender shows not significant ( $p$ value $=0.134$ )

The association between quality of life under energy and fatigue with gender shows not significant ( $p$ value $=0.206$ ).

The association between quality of life under emotional well-being with gender shows significant ( $p$ value $=0.043$ ).

\begin{tabular}{|c|c|c|c|c|c|}
\hline \multirow[t]{2}{*}{ Gender } & \multicolumn{2}{|c|}{$\begin{array}{l}\text { Role limitations due to } \\
\text { physical health }\end{array}$} & \multirow{2}{*}{$x^{2}$ value } & \multirow{2}{*}{$\begin{array}{c}p \\
\text { value }\end{array}$} & \multirow{2}{*}{ Inference } \\
\hline & $\begin{array}{l}\leq \text { median } \\
(\leq 50)\end{array}$ & $\begin{array}{l}>\text { median } \\
\quad(>50)\end{array}$ & & & \\
\hline Male & 62 & 55 & \multirow{2}{*}{0.956} & \multirow{2}{*}{0.328} & \multirow{2}{*}{$\begin{array}{c}\text { Not } \\
\text { significant }\end{array}$} \\
\hline Female & 70 & 48 & & & \\
\hline
\end{tabular}

$\chi^{2}$ at 0.05 level of significance

\begin{tabular}{|c|c|c|c|c|c|}
\hline \multirow[t]{2}{*}{ Gender } & \multicolumn{2}{|c|}{$\begin{array}{l}\text { Role limitations } \\
\text { due to emotional } \\
\text { problems }\end{array}$} & \multirow{2}{*}{$x^{2}$ value } & \multirow{2}{*}{$p$ value } & \multirow{2}{*}{ Inference } \\
\hline & $\begin{array}{c}\leq \\
\text { median } \\
(\leq 66.60)\end{array}$ & $\begin{array}{c}> \\
\text { median } \\
(>66.60)\end{array}$ & & & \\
\hline Male & 53 & 64 & \multirow{2}{*}{2.250} & \multirow{2}{*}{0.134} & \multirow{2}{*}{$\begin{array}{c}\text { Not } \\
\text { significant }\end{array}$} \\
\hline Female & 65 & 53 & & & \\
\hline
\end{tabular}

$\chi^{2}$ at 0.05 level of significance

\begin{tabular}{|c|c|c|c|c|c|}
\hline \multirow[t]{2}{*}{ Gender } & \multicolumn{2}{|c|}{ Energy/fatigue } & \multirow[b]{2}{*}{$x^{2}$ value } & \multirow[b]{2}{*}{$p$ value } & \multirow[b]{2}{*}{ Inference } \\
\hline & $\begin{array}{c}\quad \leq \\
\text { median } \\
(\leq 50)\end{array}$ & $\begin{array}{c}> \\
\text { median } \\
(>50)\end{array}$ & & & \\
\hline Male & 69 & 48 & \multirow{2}{*}{1.602} & \multirow{2}{*}{0.206} & \multirow{2}{*}{$\begin{array}{c}\text { Not } \\
\text { significant }\end{array}$} \\
\hline Female & 79 & 39 & & & \\
\hline
\end{tabular}

$\chi^{2}$ at 0.05 level of significance

Table 24: Association between quality of life score under "Emotional well-being" with gender $(\mathbf{n}=\mathbf{2 3 5})$.

\begin{tabular}{|c|c|c|c|c|c|}
\hline \multirow[t]{2}{*}{ Gender } & \multicolumn{2}{|c|}{ Emotional well-being } & \multirow[b]{2}{*}{$x^{2}$ value } & \multirow[b]{2}{*}{$p$ value } & \multirow[b]{2}{*}{ Inference } \\
\hline & $\begin{array}{c}\leq \text { median } \\
(\leq 54)\end{array}$ & $\begin{array}{c}>\text { median } \\
(>54)\end{array}$ & & & \\
\hline Male & 51 & 66 & \multirow{2}{*}{4.088} & \multirow{2}{*}{0.043} & \multirow{2}{*}{ Significan } \\
\hline Female & 67 & 51 & & & \\
\hline
\end{tabular}

$\chi^{2}$ at 0.05 level of significance

\begin{tabular}{|c|c|c|c|c|c|}
\hline \multirow[t]{2}{*}{ Gender } & \multicolumn{2}{|c|}{ Social functioning } & \multirow[b]{2}{*}{$x^{2}$ value } & \multirow[b]{2}{*}{$p$ value } & \multirow[b]{2}{*}{ Inference } \\
\hline & $\begin{array}{l}\leq \text { median } \\
(\leq 62.50)\end{array}$ & $\begin{array}{l}>\text { median } \\
(>62.50)\end{array}$ & & & \\
\hline Male & 71 & 46 & \multirow{2}{*}{0.999} & \multirow{2}{*}{0.318} & \multirow{2}{*}{$\begin{array}{c}\text { Not } \\
\text { significant }\end{array}$} \\
\hline Female & 79 & 39 & & & \\
\hline
\end{tabular}

$\chi^{2}$ at 0.05 level of significance 


\begin{tabular}{|c|c|c|c|c|c|}
\hline \multirow[t]{2}{*}{ Gender } & \multicolumn{2}{|c|}{ Pain } & \multirow[b]{2}{*}{$x^{2}$ value } & \multirow[b]{2}{*}{$p$ value } & \multirow[b]{2}{*}{ Inference } \\
\hline & $\begin{array}{c}\leq \\
\text { median } \\
(\leq 55)\end{array}$ & $\begin{array}{c}>\text { median } \\
(>55)\end{array}$ & & & \\
\hline Male & 60 & 57 & \multirow{2}{*}{1.536} & \multirow{2}{*}{0.215} & \multirow{2}{*}{ Not significant } \\
\hline Female & 70 & 48 & & & \\
\hline
\end{tabular}

$\chi^{2}$ at 0.05 level of significance

\begin{tabular}{|c|c|c|c|c|c|}
\hline \multirow[t]{2}{*}{ Gender } & \multicolumn{2}{|c|}{ General health } & \multirow[b]{2}{*}{$x^{2}$ value } & \multirow[b]{2}{*}{$p$ value } & \multirow[b]{2}{*}{ Inference } \\
\hline & $\begin{array}{c}\leq \text { median } \\
\quad(\leq 50)\end{array}$ & $\begin{array}{c}>\text { median } \\
\qquad>50)\end{array}$ & & & \\
\hline Male & 60 & 57 & \multirow{2}{*}{5.323} & \multirow{2}{*}{0.021} & \multirow{2}{*}{ Significant } \\
\hline Female & 78 & 40 & & & \\
\hline
\end{tabular}

$\chi^{2}$ at 0.05 level of significance

\begin{tabular}{|c|c|c|c|c|c|}
\hline \multirow{2}{*}{$\begin{array}{l}\text { Socio } \\
\text { economic } \\
\text { status }\end{array}$} & \multicolumn{2}{|c|}{ Quality of life } & \multirow[b]{2}{*}{$\begin{array}{c}X^{2} \\
\text { value }\end{array}$} & \multirow[b]{2}{*}{$p$ value } & \multirow[b]{2}{*}{ Inference } \\
\hline & $\begin{array}{r}\leq \text { median } \\
(\leq 457.5)\end{array}$ & $\begin{array}{r}>\text { median } \\
(>457.5)\end{array}$ & & & \\
\hline 1 & 4 & 5 & \multirow{5}{*}{11.189} & \multirow{5}{*}{0.025} & \multirow{5}{*}{ Significant } \\
\hline 2 & 47 & 32 & & & \\
\hline 3 & 48 & 41 & & & \\
\hline 4 & 17 & 31 & & & \\
\hline 5 & 2 & 8 & & & \\
\hline
\end{tabular}

$\chi^{2}$ at 0.05 level of significance

The association between quality of life under social functioning with gender shows not significant ( $p$ value $=0.318$ ).

The association between quality of life under pain with gender shows not significant $(p$ value $=0.215)$.

The association between quality of life under general health with gender shows significant $(p$ value $=0.021)$.

Similarly. In the study ofLaila M Matalqah et al. also described similar association between health related quality of life and gender. ${ }^{15}$ This shows both males and females have different dimensions in different domains of health related quality of life.

Socioeconomic status can affect the health related quality of life through variety of mechanisms including illiteracy rate, employment level and income level of the family along with physical and mental health comorbidities. The association between quality of life with socioeconomic status using kuppuswamy socioeconomic scale shows significance ( $p$ value $=0.025$ ). In the study of Gautam et al., also shows the poor scores in the quality of life domains were significantly associated with lower socioeconomic status, lesser education and lesser habitual physical activity of diabetic patients. ${ }^{16}$

Association between quality of life score with total number of drugs prescribed shows significant $(p$ value $=0.028)$

\begin{tabular}{|c|c|c|c|c|c|}
\hline \multirow{2}{*}{$\begin{array}{l}\text { Total number } \\
\text { of drugs } \\
\text { prescribed }\end{array}$} & \multicolumn{2}{|c|}{ Quality of life } & \multirow[b]{2}{*}{$\begin{array}{c}X^{2} \\
\text { value }\end{array}$} & \multirow[b]{2}{*}{$p$ value } & \multirow[b]{2}{*}{ Inference } \\
\hline & $\begin{array}{r}\leq \text { median } \\
(\leq 457.5)\end{array}$ & $\begin{array}{r}>\text { median } \\
(>457.5)\end{array}$ & & & \\
\hline $0-5$ & 45 & 26 & \multirow{3}{*}{7.158} & \multirow{3}{*}{0.028} & \multirow{3}{*}{ Significant } \\
\hline $5-10$ & 60 & 73 & & & \\
\hline$>10$ & 13 & 18 & & & \\
\hline
\end{tabular}

$\chi^{2}$ at 0.05 level of significance

\begin{tabular}{|c|c|c|c|c|c|}
\hline \multirow{2}{*}{$\begin{array}{l}\text { Number } \\
\text { of drugs } \\
\text { prescribed } \\
\text { from essential } \\
\text { drug list }\end{array}$} & \multicolumn{2}{|c|}{ Quality of life } & \multirow[b]{2}{*}{$\begin{array}{c}X^{2} \\
\text { value }\end{array}$} & \multirow[b]{2}{*}{$p$ value } & \multirow[b]{2}{*}{ Inference } \\
\hline & $\begin{array}{c}\leq \\
\text { median } \\
(\leq 457.5)\end{array}$ & $\begin{array}{r}>\text { median } \\
(>457.5)\end{array}$ & & & \\
\hline $0-5$ & 87 & 68 & \multirow{3}{*}{9.474} & \multirow{3}{*}{0.009} & \multirow{3}{*}{ Significant } \\
\hline $5-10$ & 30 & 41 & & & \\
\hline$>10$ & 1 & 8 & & & \\
\hline
\end{tabular}

$\chi^{2}$ at 0.05 level of significance

\begin{tabular}{|c|c|c|c|c|c|}
\hline \multirow{2}{*}{$\begin{array}{c}\text { Number } \\
\text { of drugs } \\
\text { prescribed in } \\
\text { generic name }\end{array}$} & \multicolumn{2}{|c|}{ Quality of life } & \multirow[b]{2}{*}{$\begin{array}{c}x^{2} \\
\text { value }\end{array}$} & \multirow[b]{2}{*}{$\begin{array}{c}p \\
\text { value }\end{array}$} & \multirow[b]{2}{*}{ Inference } \\
\hline & $\begin{array}{r}\leq \text { median } \\
(\leq 457.5)\end{array}$ & $\begin{array}{l}>\text { median } \\
(>457.5)\end{array}$ & & & \\
\hline 0 & 105 & 97 & \multirow{5}{*}{11.623} & \multirow{5}{*}{0.038} & \multirow{5}{*}{ Significan } \\
\hline 1 & 13 & 16 & & & \\
\hline 2 & 0 & 2 & & & \\
\hline 3 & 0 & 1 & & & \\
\hline 4 & 0 & 1 & & & \\
\hline
\end{tabular}

$\chi^{2}$ at 0.05 level of significance

\begin{tabular}{|c|c|c|c|c|c|}
\hline \multirow{2}{*}{$\begin{array}{l}\text { Number of } \\
\text { antibiotics } \\
\text { prescribed }\end{array}$} & \multicolumn{2}{|c|}{ Quality of life } & \multirow[b]{2}{*}{$\begin{array}{c}X^{2} \\
\text { value }\end{array}$} & \multirow[b]{2}{*}{$p$ value } & \multirow[b]{2}{*}{ Inference } \\
\hline & $\begin{array}{r}\leq \text { median } \\
(\leq 457.5)\end{array}$ & $\begin{array}{l}>\text { median } \\
(>457.5)\end{array}$ & & & \\
\hline 0 & 12 & 9 & \multirow{4}{*}{8.337} & \multirow{4}{*}{0.042} & \multirow{4}{*}{ Significan } \\
\hline 1 & 74 & 84 & & & \\
\hline 2 & 29 & 21 & & & \\
\hline 3 & 3 & 3 & & & \\
\hline
\end{tabular}

$\chi^{2}$ at 0.05 level of significance

Association between quality of life score with number of drugs prescribed from essential drug list shows significant ( $p$ value $=0.009$ )

Association between quality of life score with number of drugs prescribed in generic name shows significant $(p$ value $=0.038)$

Association between quality of life score with number of antibiotics prescribed shows significant $(p$ value $=0.042)$ 
Bismi, et al.: A Pros. Interventional Study on Prescription Auditing, ADR Monitoring and HRQoL of patient

\begin{tabular}{|c|c|c|c|c|c|}
\hline \multirow{2}{*}{$\begin{array}{l}\text { Number of } \\
\text { injections } \\
\text { prescribed }\end{array}$} & \multicolumn{2}{|c|}{ Quality of life } & \multirow{2}{*}{$\begin{array}{c}X^{2} \\
\text { value }\end{array}$} & \multirow{2}{*}{$\begin{array}{c}p \\
\text { value }\end{array}$} & \multirow[b]{2}{*}{ Inference } \\
\hline & $\begin{array}{r}\leq \text { median } \\
(\leq 457.5)\end{array}$ & $\begin{array}{r}>\text { median } \\
(>457.5)\end{array}$ & & & \\
\hline 0 & 5 & 0 & \multirow{7}{*}{8.904} & \multirow{7}{*}{0.179} & \multirow{7}{*}{$\begin{array}{c}\text { Not } \\
\text { Significant }\end{array}$} \\
\hline 1 & 13 & 9 & & & \\
\hline 2 & 47 & 62 & & & \\
\hline 3 & 37 & 35 & & & \\
\hline 4 & 10 & 12 & & & \\
\hline 5 & 1 & 2 & & & \\
\hline 6 & 0 & 2 & & & \\
\hline
\end{tabular}

$\chi^{2}$ at 0.05 level of significance

Association between quality of life score with number of injections prescribed shows not significant $(p$ value $=0.179)$

Polypharmacy can be cause due to comorbid conditions, ageing, hospitalization, etc. can leads to medication errors, drug interactions, drug toxicity, ADRs, and other drug related problems which may also affect physical, mental, emotional and economic factors of a patient. There is no any relevant study for assessing the relationship between health related quality of life.

\section{CONCLUSION AND RECOMMENDATIONS}

This study shows the level of drug related problems such as medication errors, drug interactions and therapeutic duplications which as assessed through prescription auditing checklist. The increased polypharmacy level, increased prescription in brand names and antibiotics and improper use of essential drug list will affect patient health conditions as well as economic conditions. Incidence of ADRs are lower in general medicine department and most of them were probable and mild type. Health related quality of life shows significance in age, gender, socioeconomic status and prescribing indicators in different aspects. This will explains the relationship between quality of life and drug therapy. In this study shows the need of improvement in the quality of prescribing pattern and in order to improve the quality of case, an action plan should be formulated and recommendations for changing the present prescribing practices are set either by providing the prescribers with the standard treatment guidelines, EDL and antibiotic policy or by following the information, education and communication (IEC) interventions. There is a need of spontaneous $\mathrm{ADR}$ reporting for monitoring and assessment of ADR. This study also warrants further research in this part of India for the development of possible intervention strategies to reduce burden of ADRs. The study shows that patients may fare differently in different dimensions of HRQoL as measured by SF36, and this tool may be useful for assessing well-being of individual patients in different physical and physiological dimensions of health in tertiary care settings.

\section{ACKNOWLEDGEMENT}

First of all, we are thanking God Almighty for the successful completion of our project work during covid pandemic. We also thanking to our guide, Dr. Dhanya Dharman, Dept. of Pharmacy Practice, ECPS, Prof. Dr. Shaiju S Dharan, Principal, ECPS, Dr, Caezer Ennies, Consultant, NIMS Medicity, TVM for helping us to make this work well.

\section{CONFLICT OF INTEREST}

The authors declare no conflict of interest.

\section{ABBREVIATIONS}

WHO: World Health Organization; SF- 36: Short Form 36; ADRs: Adverse Drug Reactions.

\section{REFERENCES}

1. Ross Sarah, Bond Christine, Rothnie Helen, Thomas Sian, Macleod Mary Joan. What is the scale of prescribing errors committed by junior doctors? A systematic review. Br J Clin Pharmacol. 2009;67(6):629-40. doi: 10.1111/j.13652125.2008.03330.x, PMID 19094162.

2. Velo Giampaolo $P$, Minuz Pietro. Medication errors: prescribing faults and prescription errors. Br J Clin Pharmacol. 2009;67(6):624-8. doi: 10.1111/j.13652125.2009.03425.x, PMID 19594530.

3. WHO. Measuring medicine prices, availability, affordability and price components; 2008. Available from:http://www.who.int/medicines/areas/access/OMS_Medicine_ prices.pdf [cited 1/9/2021].

4. WHO. The world medicines situation report. [last accessed onFeb 15 2015]; 2011.

5. WHO. How to investigate drug use in health facilities: selected drug use indicators. EDM research series No. 007; 1993 [cited May 05 2015]. Available from: http:// www.apps.who.int/medicinedocs/en/d/Js2289e/.

6. WHO. Using indicators to measure country pharmaceutical situations. [Last accessed on; 2015 May 20]. Available from: http://www.who.int/medicines/ publications/WHOTCM2006.2A.pdf [cited 1/9/2021].

7. WHO. Guide to drug financing mechanisms; 1998 [cited May 15 2015]. Available from: http://www.apps.who.int/medicinedocs/en/d/Jh2928e/7.1.2.html.

8. Available from: https://www.msdmanuals.com/home/drugs/adverse-drug-reactions/typesof- adverse-drug-reactions [cited 1/9/2021]

9. Brazier J, Ratcliffe J, Salomon J, Tsuchiya A. Measuring and valuing health benefits for economic evaluation. 2nd ed. Oxford: Oxford University Press; 2016

10. Burström K, Johannesson M, Diderichsen F. Health-related quality of life by disease and socio-economic group in the general population in Sweden. Health Policy. 2001;55(1):51-69. doi: 10.1016/s0168-8510(00)00111-1, PMID 11137188.

11. US Department of Health and Human Services. Healthy. People [cited Mar 26 2017]. Available from:https://www.healthypeople.gov/sites/default/files/ HP2020Framework.pdf; 2020 (2017).

12. Ware JE, Kosinski M, Dewey JE. How to score version two of the SF-36® Health Survey. Lincoln, (RI): Quality Metric Incorp; 2000.

13. Brazier John, Roberts Jennifer, Deverill Mark. The estimation of a preferencebased measure of health from the SF-36. J Health Econ. 2002;21(2):271-92. doi: 10.1016/s0167-6296(01)00130-8, PMID 11939242.

14. Department of Statistics. Statistical report of population and housing census in Jordan; 2016 [cited Dec 30 2016]. Available from: http://census.dos.gov.jo/ wpcontent/uploads/sites/2/2016/02/Census_results_2016.pdf.

15. Abidi Afroz, Gupta Surabhi, kansal Saurabh, Ramgopal R. Prescription auditing and drug utilization pattern in a tertiary care Teaching Hospital of Western UP. Int J Basic Clin Pharmacol. 2012;1(3):184-90. doi: 10.5455/2319-2003.ijbcp003812.

16. Balbir Dr Kaur, Rani Dr Walia. Prescription audit for evaluation of prescribing pattern of the doctors for rational drug therapy in a tertiary Care Hospital. J Drug Deliv Ther. 2013;3(5):77-80.

17. Solanki Nilay D, Shah Chaital. Prescription audit in outpatient department of multispecialty hospital in western India: an observational study. Int J Clin Trials. 2015;2(1):149. doi: 10.5455/2349-3259.ijct20150203.

18. Sah Naresh, Ramaiah Balakeshwa, Koneri Raju. The pharmacist role in clinical audit at an Indian Accredited Hospital: an interventional study. Indian J Pharm Pract. 2019;12(2):117-25. doi: 10.5530/ijopp.12.2.25.

19. Balbir Dr Kaur, Rani Dr Walia. Prescription audit for evaluation of prescribing pattern of the doctors for rational drug therapy in a tertiary Care Hospital. J Drug Deliv Ther. 2013;3(5):77-80.

20. Abidi Afroz, Gupta Surabhi, kansal Saurabh, Ramgopal R. Prescription auditing and drug utilization pattern in a tertiary care Teaching Hospital of Western UP. Int J Basic Clin Pharmacol. 2012;1(3):184-90. doi: 10.5455/2319-2003.ijbcp003812.

21. Shrivastava Meena, Uchit Ganesh, Chakravarti Ashish, Joshi Gajanan, Mahatme Mohini, Chaudhari Harshal. Adverse drug reactions reported in Indira Gandhi government Medical College and Hospital, Nagpur. J Assoc Physicians India. 2011;59:296-9. PMID 21751606. 